\title{
TRAUMA-INFORMED APPROACH IN THE DEVELOPMENT OF INCLUSIVE EDUCATION ENVIRONMENT IN THE HIGHER SCHOOL
}

\author{
Anastasiia Bednarska ${ }^{1}$, Mariana Hasiak ${ }^{2}$, Iryna Krasilych ${ }^{3}$ \\ Lviv Polytechnic National University, Lviv, Ukraine
}

\begin{abstract}
.
Introduction: According to statistics, the number of students with disability at Lviv Polytechnic National University is 374 people; the number of veteran-students is 6; the number of students-children of veterans is 811 . Moreover, there is a Ukraine-Norway Project conducted on the basis of Lviv Polytechnic providing retraining courses for veterans and their family members. In the five years of the project implementation, 428 people have been trained at Lviv Polytechnic. To meet the educational needs of those categories of students the Accessibility Services for students with disability and Veteran Services for combatants, their family members and IDPs have been established at Lviv Polytechnic. The activities of those services are aimed at providing support to students with disability, veteran students, students-family members of veterans, internally displaced persons; ensuring the provision of necessary information and assistance in higher education settings. For the successful functioning of these and similar services, it is important to study the post-traumatic stress disorder (PTSD) and the trauma-informed approach (TIA). Furthermore, the realities of Ukrainian society give impetus to the experience of traumatic events not only to the abovementioned categories of students, but also to others who do not belong to them. Therefore, it is advisable to comprehensively study and implement the traumainformed approach in the educational process to ensure inclusive education environment for each category of students with special educational needs.
\end{abstract}

Purpose: The purpose of the article is to highlight the importance of the development of trauma-informed approach to meet the needs of students experiencing trauma, students with disabilities and veteran-students particularly.

Methods: Theoretical research methods were used to determine the needs of students experiencing trauma to be met in educational process using the trauma-informed approach at higher schools of Ukraine on the example of Accessibility and Veteran Services at Lviv Polytechnic.

Results: Inclusive education has been considered as a part of social inclusion. Key issues of the development of inclusive education environment are addressed based on applying trauma-informed approach. The purpose to implement a trauma-informed approach in academic environment is identified based on scientific research data and needs assessment. The two basic concepts of trauma-informed approach realization have been developed.

For the first time in the national scientific opinion the possibilities of implementing an inclusive educational environment in the higher education 
institutions of Ukraine, taking into account the needs and problems of students experiencing trauma were described.

During the educational process, the trauma-informed approach is important to be used when detecting the following symptoms: limited ability to focus, anxious or obsessive thoughts, inability to consistently do research and attend classes, panic attacks with difficulty of breathing, rapid heartbeat, sweating, and deep agitation of short and / or long-term memory, fatigue, decreased concentration and attention, lack of initiative and motivation, irritability and increased sensitivity to stress, inappropriate behavior and poor social skills, slow response rates, difficulty in solving problems, difficulties in planning and sequencing, depression, anxiety and low self-esteem, impulsiveness, loss of taste and smell, dizziness and difficulty with balance, epilepsy and convulsions, headaches, decrease or change in vision, chronic pain, paralysis, difficulty in reading and summarizing (processing information).

Some of these characteristics are very individual, others are the opposite, and are noticeable at once. That is why it is important to disseminate information among the academic community. At the same time, the above-mentioned attributes not only to students who are experiencing/have experienced trauma, but also may concern students with mental health disorders, which in turn make it possible to create an inclusive educational environment tailored to these categories of students as well.

It is important to understand that a student with special educational needs has the same responsibilities as all other students. It is to attend classes and fulfill the basic requirements of the course. The role of the instructor is to help the student in finding solutions to fulfill these responsibilities, not to lower expectations because of the student's special educational needs, abide by the principles of confidentiality regarding the personal information of the student with special educational needs.

To address the above need, we plan to carry out further research in this field in relation to the practical work of the "No Limits" Accessibility Services and the Veteran Services at Lviv Polytechnic, taking into account the international experience, with a focus on the American and Canadian approaches.

Conclusion: To achieve the research goal and objectives in creating the environment friendly to people in difficult life circumstances the trauma-informed approach to providing educational services is suggested to be implemented. In the practice of trauma-informed approach realization, the two foci are distinguished, i.e., achieving personal development and wellness of the students experiencing trauma via special services provided for them (by Students Accessibility Services and Veteran Services at Lviv Polytechnic) and transforming the environment through educational work with the University academic community.

Keywords: students experiencing trauma, academic environment, inclusive educational environment, special educational needs, trauma-informed 
approach, PTSD, inclusive education, veteran space, students with disabilities, social inclusion

\section{The authors declare that they have no competing interests References}

Avksentieva, T. A., \& Lisnychenko, A. P. (2016). The ways of inclusive education integration into higher educational establishments of ukraine. Scientific notes of Vinnytsia State Pedagogical University named after Mikhail Kotsyubynsky. Series: Pedagogy and Psychology, 48, 135-138.

Arishchenko, A. (2018). Inclusive Educational Environment of Ukrainian Universities: Current State and Trends of Development. Pedagogical sciences: theory, history, innovative technologies, 5, 381-389.

Bondar, T. I. (2014). Creating an inclusive educational environment in the higher education system of Ukraine. Science and Education a New Dimension. Pedagogy and Psychology, 27, 20-24.

Herman, Dzh. (2019). Psychological trauma and the way to recovery: the effects of violence - from domestic harassment to political terror. Translated from English: Oksana Lizak, Oksana Nakonechna, Oleksandr Shlapak. Lviv: The Old Lion Publishing House, 424.

Karut, K. (2017). To hear trauma: Talk to leading specialists in the theory and treatment of catastrophic experiences. Trans. from English: Catherine Disa, 496.

Kolupayeva, A. A, Taranchenko, O. M, Naida, Yu. M., \& Belozerskaya, I. O (Eds.). (2011). Fundamentals of Inclusive Education: training manual. K.: «A. S. K.», 308.

Lazorenko, B. P. (2015). Paradoxical reaction in the socio-psychological technologies of coping with psychotrauma and PTSD. Psychological assistance to a person experiencing the consequences of traumatic events: collect. of articles of the Ukrainian-Polish scientific seminar, 68-76.

Myronchak, K. V. (2012). Psychological impact of fear of death on the individual. Bulletin of the Lviv State University of Internal Affairs, 2(2), 361-370.

Osadko, O. Yu. (2015). Actual problems of counselling for victims of conflict in the East of Ukraine. Psychological assistance to a person experiencing the consequences of traumatic events: collect. of articles of the UkrainianPolish scientific seminar, 77-87.

Simaeva, I. N., \& Khitryuk, V. V. (2014). Inclusive educational space: SWOTanalysis. Bulletin of the Baltic Federal University named after I. Kant, 5, 31-39.

Fert, O. H. (2014). Theoretical approaches to the organization of inclusive education in the context of education of student youth in higher education. Ukrainian and Canadian experience. Innovative Approaches to Educating Student Youth in Higher Education: Mater. of the International Scientific and Practical Conference, 263-270. 
Blank Jr, Arthur S. (1985). "Irrational Reaction to Post-Traumatic Stress Disorder and Vietnam Veterans". In Sonnenberg, Stephen M., Blank Jr., Arthur S., \& Talbott, John. (Eds.), The Trauma of War: Stress and Recovery in Vietnam Veterans. Washington, DC: American Psychiatric Press.

Bloom, Sandra L. (2009). The Sanctuary Model: A Trauma Informed Operating System for Organizations. Center for Nonviolence \& Social Justice. School of Public Health, Drexel University. Retrieved from: www.sanctuaryweb.com

Centers for Disease Control and Prevention. (2019). Preventing Adverse Childhood Experiences: Leveraging the Best Available Evidence. Atlanta, GA: National Center for Injury Prevention and Control, Centers for Disease Control and Prevention, 38. Retrieved from: https://www.cdc.gov/violenceprevention/pdf/preventingACES-508.pdf

Davoine, F., \& Gaudilliere, J. (2004). History beyond Trauma.New-York: Other Press.

Felman, S., \& Laub, D. (1991). Testimony: Crises of Witnessing in Literature, Psychoanalysis and History. New York: Routledge, 312.

Harris, M., \& Fallot, R.D. (2001). Using trauma theory to design service systems. New Directions For Mental Health Services, 89, 1-103.

Herman, J. (2000). Father-Dauther Incest. Harvard University Press, 336.

Klinic Community Health Centre. (2013). The Trauma Toolkit Second Edition. A resource for service organizations and providers to deliver services that are trauma-informed. Retrieved from: https://trauma-informed.ca/wpcontent/uploads/2013/10/Trauma-informed_Toolkit.pdf

Lifton, Robert J. (1979). The Broken Connection: On Death and the Continuity of Life. New York: Basic, 495.

Onno van der Hart, Nijenhuis, E., \& Steele, K. (2006). The Haunted Self: Structural Dissociation and the Treatment of Chronic Traumatization. New York: Norton, 420.

Rodrigue-Pare, J. (2011). Post-traumatic stress disorder and the mental health of military personnel and veterans. Ottawa: Library of Parliament, 16.

Sareen, J., Cox, B.J., Stein, M.B., Afifi, T.O., Fleet, C., \& Asumdson, G.J. (2007). Physical and Mental Comorbidity, Disability, and Suicidal Behaviour Associated with Post traumatic Stress Disorder in a Large Community Sample. American Psychosomatic Society, 69, 242-248.

University of Manitoba. (2019). Student accessibility services handbook for faculty and staff Equal Access for all, 51. Retrieved from: https://umanitoba.ca/student/accessibility/media/SAS-Handbook.pdf

Van Ameringen, M., Mancini, C., Patterson, B., \& Boyle, M. H. (2008). PostTraumatic Stress Disorder in Canada. CNS Neuroscience \& Therapeutics, 14, 171-181.

Van der Kolk, Bessel A. (2014). The Body Keeps the Score: Mind, Brain and Body in the Transformation of Trauma. New York: Viking, 464 


\title{
ЗАСТОСУВАННЯ ТРАВМА-ПОІНФОРМОВАНОГО ПІДХОДУ У ФОРМУВАННІ ІНКЛЮЗИВНОГО ОСВІТНЬОГО СЕРЕДОВИЩА У ЗАКЛАДІ ВИЩОЇ ОСВІТИ
}

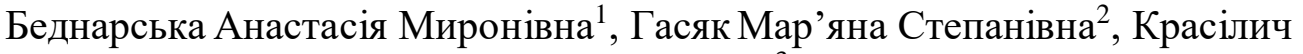 \\ Ірина Олегівна ${ }^{3}$
}

Національний університет «Львівська політехніка»

${ }^{1}$ Магістр соціальної роботи, кафедра соціології та соціальної роботи, фахівчиня Міжнародного центру професійного партнерства «Інтеграція»

${ }^{2}$ Аспірантка кафедри соціології та соціальної роботи, магістр міжнародних відносин, фахівчиня Міжнародного центру професійного партнерства «Інтеграція»

${ }^{3}$ Кандидат економічних наук, фахівчиня Міжнародного центру професійного партнерства «нтеграція»

Розглянуто ключові питання формування інклюзивного освітнього середовища у вищій школі через застосування травма-поінформованого підходу для забезпечення освітніх потреб студентів, які пережили/переживають травматичні події. Обтрунтовано важливість розвитку простору для студентів з інвалідністю та студентів-ветеранів в академічному середовищі. У практиці формування інклюзивного освітнього середовища через застосування травма-поінформованого підходу виділено два напрямки: досягнення особистого розвитку через роботу фахівиів (Служби доступності та Ветеранської служби у Львівській політехнічі) та трансформачію академічного середовища через інформування викладачів, студентів та адміністрації університету. Обгрунтування необхідності застосування травма-поінформованого підходу у процесі формування інклюзивного освітнього середовища здійснено завдяки застосуванню теоретичних методів - систематизації та аналізу джерел, порівняння $i$ узагальнення отриманої інформації, а також методу емпіричного дослідження - спостереження за людьми, що пережили/переживають травматичні подї.

Ключові слова: студенти, які пережили/переживають травматичні події, академічне середовище, інклюзивне освітнє середовище, особливі освітні потреби, травма-поінформований підхід, посттравматичний стресовий розлад, ветеранський простір, студенти з інвалідністю, соиіальна інклюзія.

Постановка проблеми. У Національному університеті «Львівська політехніка» триває процес формування інклюзивного освітнього середовища. Згідно з Наказом Ректора №43-10 від 14 березня 2017 року в Університеті створено Службу доступності до можливостей навчання «Без обмежень» (далі - Служба доступності). Станом на жовтень 2019 року в Університеті навчалося 374 студенти з інвалідністю. Служба доступності спрямовує свою діяльність на допомогу студентам з інвалідністю, зумовлену різними нозологіями. 
Сучасне українське суспільство функціонує в умовах війни. Тому все частіше виявляється необхідність роботи зі студентами, які пережили травматичні події; найчастіше такими студентами стають безпосередні учасники бойових дій, члени їхніх сімей та внутрішньо переміщені особи. За даними на 2019 рік у Львівській політехніці навчаються: 6 студентів-осіб, визнаних учасниками бойових дій, 811 студентів-дітей учасників бойових дій. Також на базі Університету проводяться курси із соціальної адаптації та професійної перепідготовки військовослужбовців, звільнених у запас та членів їх сімей (Проєкт «Україна-Норвегія»). За п’ять років реалізації проєкту у Львівській політехніці навчання пройшли 428 людей, які представляють перелічені категорії. Саме тому навесні 2019 р. Наказом Ректора №135-1-10 від 20 березня було створено Ветеранську службу для учасників бойових дій, членів їхніх сімей та внутрішньо переміщених осіб (далі - Ветеранська служба).

Діяльність Ветеранської служби має на меті надання навчальних та допоміжних послуг студентам-ветеранам війни, студентам-членам сімей ветеранів війни, внутрішньо переміщеним особам; забезпечення надання необхідної інформації та допомоги в умовах навчання у закладі вищої освіти. Для успішного функціонування цієї та подібних служб важливим $\epsilon$ вивчення травма-поінформованого підходу (ТПП) та посттравматичного стресового розладу (ПТСР). Важливо зазначити, що не всі учасники бойових дій, члени їхніх сімей чи внутрішньо переміщені особи, а також люди 3 інвалідністю мають ПТСР. Разом 3 тим, студенти, котрі не належать до жодної з цих груп, можуть мати ПТСР і потребувати застосування травмапоінформованого підходу в організації навчання. Як свідчить американський досвід, більш, ніж половина студентів-ветеранів мають ту чи іншу форму інвалідності. Зокрема, за даними Ветеранської служби Фредерік Ком'юниті Коледжу (США) 58 \% студентів-ветеранів мають інвалідність. Саме тому травма-поінформований підхід та вивчення i поширення інформації про ПТСР у академічному середовищі невідривно від процесу формування інклюзивного освітнього середовища.

Аналіз останніх досліджень і публікацій. Травму у різних контекстах вивчали науковці, зокрема такі вітчизняні дослідники, як: К.В.Мирончак (2012; досліджує вплив страху смерті на особу); О.Ю.Осадько (2015, вивчає психологічну допомогу потерпілим від конфлікту); Б.П. Лазоренко (2015, розглядає опанування психотравми i ПТСР як парадоксальну реакцію в контексті соціально-психологічних технологій).

Визначними дослідженнями травми є роботи таких закордонних дослідників і практиків, як-от: Джей Ліфтон (1979) - досліджував травму крізь призму смерті (дослідження Хіросіми, В'єтнаму, Голокосту, загрози ядерної війни); Дорі Лауб (1991) - пережив Голокост, психоаналітик, який займається клінічним лікування травм тих, хто вижив у катастрофічних 
ситуаціях; Франсуаза Давуан та Жан-Макс Годієр (2004) - психоаналітикипрактики, які досліджують взаємозв'язок божевілля та травми; Джудіт Герман (2000) - лікарка-психіатр (Гарвардська медична школа) - досліджує взаємозв'язок травми та інцесту; Бессель А. ван дер Кольк (2014) - психіатр - досліджує ПТСР, роль мозку та тіла в етіології та лікування травми; Онно ван дер Гарт (2006) - розглядає дисоціативні розлади як основоположний фактор травматичного досвіду; Артур-Бланк молодший (1985) психоаналітик (Вашингтон), психіатр, який одним 3 перших визнав вплив травми на солдатів, що повернулися 3 війни у В'єтнамі, i в рамках Адміністрації ветеранів займався лікуванням травми і спеціальним лікуванням ПТСР у ветеранів війни. Джудіт Герман (2019) - лікаркапсихіатр, професорка Гарвардського університету, яка спеціалізується на терапії жертв насильства, виміру психологічної травми та комплексному процесі видужання.

Створення інклюзивного освітнього середовища має важливий вплив на соціалізацію осіб, що пережили чи переживають травму загалом. Вагомий внесок у дослідження особливостей формування інклюзивного освітнього середовища зробили такі дослідники: Т.А. Авксеньтєва (2016), А. Аріщенко (2018), T.I. Бондар (2011), А.А. Колупаєва (2014), О.Г. Ферт (2014). Разом 3 тим, дослідження формування інклюзивного освітнього середовища на засадах застосування травма-поінформованого підходу наразі відсутні.

Мета статті - розробити рекомендації до застосування травмапоінформованого підходу до викладання та роботи зі студентами / слухачами / здобувачами в Університеті як складової формування інклюзивного освітнього середовища для людей, які пережили / переживають травматичні події.

Виклад основного матеріалу. Концепція формування інклюзивного освітнього середовища у закладах вищої освіти сьогодні є актуальною для всіх, хто має відношення до організації інклюзивного навчального процесу, надання інклюзивних освітніх послуг, а також потребує адаптованих умов в процесі навчання. Відтак, зосередимо свою увагу на важливих аспектах формування інклюзивного освітнього середовища у ЗВО для осіб, які пережили травму. Створення інклюзивного освітнього середовища базується на принципах: соціальне спрямування освітнього процесу (допоможе студенту, який пережив травму, включитись у більшість сфер життєдіяльності суспільства); індивідуалізація та персоніфікація освітнього середовища (передбачає адаптацію освітнього процесу до потреб та особливостей кожного студента) (Симаева, \& Хитрюк, 2014); мотивація та стимуляція внутрішнього потенціалу особи; максимізація соціальних ресурсів; вимогливість у поєднанні з гуманізмом (Авксентьєва, 2016).

Враховуючи реалії, в яких функціонує українське суспільство вже понад п'ятиліття, важливо розглядати формування інклюзивного освітнього середовища, зважаючи на потреби людей, які пережили / переживають 
травматичні події у житті. Ніхто не застрахований від переживання травматичного досвіду. У численних дослідженнях, серед яких «Досвід неблагополучного дитинства» Вінсента Фелітті М.Д. та Роберта Анди М.Д. (Preventing Adverse Childhood Experiences: Leveraging the Best Available Evidence, 2019), висловлюється припущення, що принаймні 75\% населення пережило хоча б одну травматичну подію в їхньому житті.

Особи різного віку, соціально-економічного статусу, культури, релігії та сексуальної орієнтації можуть зазнати травми. Сім’ї можуть травмуватися подією, що трапляється з одним або більшою кількістю ії членів. Навіть люди, які не отримали безпосередньо травматичного досвіду, можуть переживати травматичні події через тісний зв'язок з людиною, яка пережила / переживає їх. Своєю чергою, громади можуть зазнавати травматичних впливів через травми, які впливають на їх окремих членів. Цілі культури можуть зазнавати травматичного впливу, у ситуаціях геноциду, війни, насильної асиміляції тощо. Відтак сьогодні українське суспільство, яке знаходиться у стані війни, може вважатися таким, яке переживає травматичні подіі.

Не виключено, що травматичний досвід може набувати організація, яка працює із травмованими людьми. Це відбувається тоді, коли така організація регулярно надає послуги людям, що зазнали травми. Враховуючи цей факт, можна припустити, що поширення інформації про травму та застосування травма-поінформованого підходу допомагатиме не лише споживачам послуг, але і тим, хто їх надає.

«Хоча травма може бути головною причиною труднощів багатьох людей і існує усвідомлення іiі важливої складової в процесі одужання (в установах громадського психічного здоров'я та соціальних служб), проте виявлення та усунення травми є нечастим явищем» (Harris, \& Fallot, 2001). Саме тому для процесу ефективної взаємодії важливе усвідомлення впливу травми на людей. «Служби, поінформовані про травми, не повинні бути зосереджені на лікуванні симптомів або синдромів, пов'язаних з травмою. Швидше, незалежно від їх основної місіі - їх зобов'язання полягає в наданні послуг таким чином, щзо відповідає потребам тих, хто постраждав від травми» (Harris, \& Fallot, 2001).

По суті, травма-поінформований підхід замінює стигматизацію людини як «хворої» до такої, що зазнала впливу «травми». Перегляд травми зміщує розмову з питання «Що з Вами не так?» до «Що з Вами трапилося?».

Основними принципами травма-поінформованого підходу є:

-визнання - першочергово, визнання травми як такої;

-безпека;

-довіра;

-вибір та контроль;

-співчуття;

-співпраця; 
-акцент на сильних сторонах (The trauma Toolkit, 2013).

Постачальник послуг / Служба / Система / Організація поінформована про травму: усвідомлює широкий вплив травми та розуміє потенційні шляхи до зцілення; розпізнає ознаки та симптоми травми у персоналу, клієнтів, пацієнтів, мешканців та інших осіб, які є учасниками системи; реагує на їх потреби, повністю інтегруючи знання про травму в політику, процедури та практику.

Першочергової важливості в контексті впровадження травмапоінформованого підходу має розуміння сутності травми та іiі видів. Зокрема, фахівці виділяють групи травм. Міжособистісна травма: насильство над дітьми; сексуальне насильство; історична травма; домашнє насильство; втрата через вбивства; катування та насильницьке ув'язнення; насильство над людьми похилого віку. Зовнішня травма: жертви війни; жертви злочинів (може бути і міжособистісним); раптова смерть близької людини; втрата внаслідок суӥциду; втрата близької людини внаслідок вбивства; раптова і несподівана втрата роботи, житла, стосунків; життя в злиднях; стихійні лиха; техногенні катастрофи. Травма розвитку: насильство над дітьми та нехтування ними; діти, які стають свідками насильства у сім'ї (The trauma Toolkit, 2013).

Посттравматичний стресовий розлад $\epsilon$ одним із найскладніших наслідків травми. Опис та симптоми ПТСР відносяться ще до часів Стародавньої Греції. Однак, лише в 1980 р. сукупність симптомів, віднесених до психічної хвороби внаслідок страждань ветеранів війни у B'єтнамі, було включено до Посібника $з$ діагностики та статистики (DSM) Американської психіатричної асоціації. Тяжкість впливу травми залежить від віку, розвитку людини та джерела травми, тобто від того, чи була травма реляційною, спричинена близьким, кимось поза сім'єю, стихійним лихом, війною тощо.

За даними Канадської асоціації психічного здоров'я, у Канаді діагностовано ПТСР майже в кожного з 10 людей. Більшість людей можуть відчувати окремі симптоми без розвитку ПТСР. Канадські дослідження визнають, що ветерани бойових дій, миротворці, особи, які вціліли після терористичного нападу та популяції аборигенів зазнають найбільшого ризику щодо розвитку ПТСР (Sareen, Cox, Stein, Afifi, Fleet, \& Asumdson, 2007). Частина канадських дослідників ідентифікує жінок як тих, в кого вдвічі частіше, ніж у чоловіків розвивається ПТСР (Van Ameringen, Mancini, Patterson, \& Boyle, 2008). 3 огляду на час переживання стресових травм очікується, що $30 \%$ солдатів, які брали участь в бойових діях, будуть переживати ПТСР або клінічну депресію (Rodrigue-Pare, 2011).

Люди реагують на травматичні події по-різному, відповідно до своїх індивідуальних навичок подолання стресу та наявних систем підтримки. Дослідження впливу травми на різні групи населення показує, що переважна більшість людей, які особисто не постраждали від жахливої трагедії, не 
зазнають довготривалої шкоди. У людей може розвиватись ПТСР, коли вони реагують на пережиті травматичні події, емоційно блокуючи їх під час i після травми. Це впливає на те, як вони організують своє життя, і часто змушує сприймати наступні стресові життєві події через досвід попередньої травми. Орієнтація на минуле, таким чином, поступово позбавляє їх життя сенсу та задоволення.

Розгляд ПТСР, зазвичай, зосереджується на трьох елементах:

1.Повторне переживання спогадів про травматичний досвід $\mathrm{y}$ зображеннях, запахах, звуках та фізичних відчуттях. Переважно спогади супроводжуються екстремальними фізіологічними станами, а також психологічним стресом, який може включати тремтіння, плач, страх, лють, розгубленість чи параліч.

2.Уникнення нагадувань про травму, а також емоційне оніміння або відсторонення. Це пов'язано з неможливістю відчути задоволення та із загальною відмовою від продовження життя, а також супроводжується посиленим збудженням, дратівливістю, проблемами 3 пам'яттю та концентрацією, порушенням сну, перебільшеною реакцією на стрес.

3.Уявлення, яке спричиняє проблему у визначенні теперішнього i травматичного минулого так, що травмовані люди реагують на багато звичайних розчарувань ніби на травматичні події (The trauma Toolkit, 2013).

Основна проблема ПТСР полягає в тому, що певні відчуття чи емоції, пов'язані 3 травматичними переживаннями, не зникають, продовжують повертатися і не згасають з часом. Люди з ПТСР не в змозі забути про подію і мінімізувати іiі вплив. Вони можуть не усвідомлювати, що їх теперішні інтенсивні почуття пов'язані з минулим, тому вони можуть звинувачувати своє теперішнє оточення у тому, як вони почуваються.

Сандра Блум (2009), лікарка, визначила сім зобов'язань організацій, які використовують травма-поінформований підхід, а саме: (1) ненасильство - сприяння формуванню навичок безпеки та прихильності до вищої мети; (2) емоційний інтелект - допомога у вивченні навичок емоційного менеджменту; (3) соціальне навчання - допомога у формуванні когнітивних навичок; (4) відкрита комунікація - допомога в подоланні бар'єрів для здорової комунікації, навчання щодо вирішення конфліктів, зменшення навичок самозахисту та самокоригування, навчання здорових кордонів; (5) соціальна відповідальність - сприяння формуванню навичок соціального зв'язку, налагодженню здорових стосунків та встановленню справедливості; (6) демократія - допомога у формуванні громадянських навичок самоконтролю, самодисципліни та управління здоровим авторитетом; (7) зростання та зміни - допомога в «опрацюванні» втрати та підготовці до майбутнього.

Ефекти травми дуже індивідуальні, але загалом у людей, які зазнали травми, можливі порушення фізичного, емоційного, поведінкового, 
когнітивного, духовного, нейробіологічного та реляційного аспектів особистості.

Фізичні відхилення найчастіше проявляються в таких формах: алкоголізм та зловживання алкоголем; хронічна обструктивна хвороба легень; смерть плоду; вживання наркотиків; ішемічна хвороба серця; захворювання печінки; ризик сексуального насильства; кілька сексуальних партнерів; хвороби, що передаються статевим шляхом; куріння; спроби самогубства; непередбачені вагітності; ранній початок куріння; рання ініціатива сексуальної активності; підліткова вагітність.

Емоційні прояви: депресія; почуття відчаю, безнадії та безпорадності; провина; ганьба; самозвинувачення; самоненависть; відчуття себе як поганої людини; тривога; екстремальна вразливість; панічні атаки; побоювання; нав'язливі стани та нав'язлива поведінка; виснаження; дратівливість, гнів і обурення; емоційне оніміння; нав'язливі думки; труднощі у відносинах.

Поведінкові зміни: зловживання алкоголем; вживання наркотиків; азартні ігри; саморуйнівна поведінка; соціальне виключення; вибір друзів, які можуть нашкодити; суїцидальна поведінка; насильство та агресія стосовно інших.

Когнітивні порушення: зникають спогади про травму; забагато спогадів про травму; складність у прийнятті рішень; зниження здатності до концентрації уваги; прокрастинація; відхід від нормальної щоденної рутини; думки про самогубство.

Духовна сфера: відчуття, що життя немає мети та сенсу; відсутність відповідей на питання «хто я такий?», «куди я йду?», «чи я, насправді, маю значення?»; думки про зло; відчуття ізоляції від навколишнього світу.

Нейробіологічні порушення: надмірне вироблення гормону стресу, що не повертається до норми після активації впродовж годин, днів, i проявляється тремтінням, перебільшеною реакцією на стрес; постійно «увімкненою тривогою в мозку», що створює труднощі з впізнанням осіб, призводить до неправильного тлумачення поведінки інших людей як загрозливих, зумовлює проблеми зі сном, уникнення ситуацій, які сприймаються як страхітливі; частина структур мозку може змінюватися ставати меншою чи більшою, ніж належить.

Релячійні порушення: труднощі у відчутті любові, довіри у стосунках; зменшення інтересу до сексуальної активності внаслідок травми; емоційне дистанціювання від інших; стосунки можуть характеризуватися гнівом та недовірою; неможливість підтримувати стосунки; труднощі батьківства.

Отже, травма може призвести до: змін головного мозку; порушення імунної системи; посилення фізичного та психічного напруження; зниження довіри; труднощів із прихильністю та конфліктних стосунків; жорсткої чи хаотичної поведінки. Саме тому, системи та організації, що $\epsilon$ поінформованими про травму, здійснюють свою діяльність, базуючись на 
розумінні психологічного, неврологічного, біологічного, соціального та духовного впливу, який може мати травма та насильство.

Результати теоретичного дослідження показали важливість застосування травма-поінформованого підходу в роботі зі студентами у закладі вищої освіти. Враховуючи специфіку особливих освітніх потреб людей, які пережили / переживають травму, важливим є застосування комплексного підходу в оцінюванні потреб цієї категорії студентів. Можна виділити два основні напрями застосування травма-інформованого підходу у формуванні інклюзивного освітнього середовища у Львівській політехніці: (1) безпосередня підтримка та допомога, яка надається Службою доступності та Ветеранською службою (The trauma Toolkit, 2013); (2) формування поінформованого щодо травми середовища завдяки роботі 3 академічною спільнотою Університету, першочергово 3 викладачами та студентами (Student accessibility services handbook for faculty and staff, 2019, p. 9).

Перший напрям передбачас нові стандарти практики у роботі 3 людьми, які пережили / переживають травматичний досвід, як-от:

- налагодження відносини на основі поваги, довіри та безпеки;

- використання перспективи сильних сторін;

- постановка запитань та тверджень з розумінням та без засуджень;

- розгляд поведінки людини з урахуванням того, що це був іiі спосіб подолати складну ситуацію, спосіб вижити, і вивчення альтернативних способів поведінки як частина процесу відновлення;

- допомога людині у врегулюванні негативних емоцій;

- визнання того, що ситуація, яка сталась 3 людиною, була поганою, але сама людина не є такою;

- визнання того, що людина не мала контролю над тим, що 3 нею сталося. Те, як люди пережили травматичні події, насправді було їхнім способом протистояти тому, що з ними відбувається;

- надання людині відповідної та фахової інформації, стосовно проблеми в процесі запропонування їй послуг, з подальшим використанням цих знань під час надання послуг;

- відслідковування та зменшення можливості виникнення тригерів та реакцій на травми.

Другий напрям передбачас найважливіші елементи роботи 3 людьми цієї категорії у $3 В 0$ та може слугувати джерелом рекомендацій для викладачів у реалізації навчального процесу.

Деякі студенти не знають про ПТСР і не усвідомлюють його у себе, але викладач може спостерігати порушення концентрації уваги, «необережні» помилки, надзвичайну неспокійність або «прискіпливість», неефективну організацію та управління часом.

У цьому випадку корисно приватно обговорити зі студентом свої спостереження, запропонувавши йому/їй підтримку в навчанні, як-от: репетиторство, якщо це доречно, та/або проконсультуватися 3 
Координатором 3 доступності щодо вибору стратегії навчання у певному випадку. Важливо пам'ятати, що студент також має обов'язки, включаючи: відвідування заняття та виконання всіх вимог курсу.

При вияві ознак ПТСР викладач може самостійно змінити навчальну стратегію викладання або звернутися у відповідну службу підтримки по роботі з такими студентами.

Використання деяких навчальних стратегій для підготовки курсу, викладання лекцій, розробки завдань та іспитів не тільки допоможе досягти успіху студентам з особливими освітніми потребами у групах, але буде корисним і для інших студентів цих груп.

Рекомендації для викладачів:

- конфіденційність та відсутність фонового шуму ефективні у спілкуванні зі студентами з ПТСР;

- надання інформації у письмовій формі для подальшого використання може допомогти компенсувати обмежену короткочасну пам'ять і увагу;

- використання аудіозапису занять 3 лекціями для студентів, які мають труднощі 3 обробкою слухової інформації та/або одночасним слуханням і конспектуванням;

- друковані копії нотаток та роздаткових матеріалів;

- підбирати добре організовані тексти із посібників, такі як підсумки розділів, словники, покажчики;

- заздалегідь забезпечити доступні списки книг та інші матеріали;

- вказати на основні моменти перед переглядом відео чи фільмів;

- чітко вказати основні питання лекції, використовуючи письмові та усні прийоми для наголосу на них;

- підкреслювати зв'язки між ідеями, використовуючи візуальні, а також словесні методи (наприклад, карти, схеми);

- використовувати діаграми та графіки, коли це можливо, щоб доповнити усне подання інформації;

- чітко пояснювати завдання усно та письмово, із встановленими строками; та питань;

- змінювати тестові питання, надзвичайно складної структури речень

- заохочувати групову роботи, коли це можливо (наприклад, мозковий штурм, завдання).

Висновки і перспективи подальших розвідок. Отже, формування інклюзивного освітнього середовища у закладі вищої освіти важливо здійснювати 3 урахуванням травма-поінформованого підходу. Під час навчального процесу травма-поінформований підхід важливо використовувати при виявленні наступних ознак: обмежена здатність зосередження уваги, тривожні або нав'язливі думки, нездатність послідовно займатися дослідженнями і відвідувати заняття, панічні атаки з труднощами дихання, прискорене серцебиття, пітливість і глибокий страх, порушення коротко та/або довгострокової пам'яті, втома, зниження концентрації та уваги, відсутність ініціативи та мотивації, дратівливість і підвищена чутливість до стресу, невідповідна поведінка та погані соціальні навички, 
зниження швидкості реакції, складність 3 вирішенням проблем, плануванням та послідовністю дій, депресія, тривога та низька самооцінка, імпульсивність, втрата смаку i запаху, запаморочення i труднощі 3 рівновагою, епілепсія та судоми, головні болі, зниження або зміна зору, хронічний біль, параліч, труднощі з читанням і конспектуванням (обробкою інформації).

Деякі з цих характеристик є дуже індивідуальними, інші - навпаки, і $є$ помітні відразу. Саме тому важливим $\epsilon$ поширення інформації серед академічної спільноти. Разом з тим, перелічені ознаки першочергово, крім студентів, які пережили / переживають травму, можуть стосуватися студентів з ментальними порушеннями здоров'я, а це, своєю чергою, дозволяє формувати інклюзивне освітнє середовище з урахуванням цих категорій студентів.

Важливо розуміти, що у студента 3 особливими освітніми потребами $\epsilon$ такі ж обов'язки, як і у всіх студентів: відвідувати заняття і виконувати основні вимоги курсу, а роль викладача - допомогти студенту в пошуку рішень для виконання цих обов'язків, не знижувати очікування щодо успішності студента через його особливі освітні потреби, дотримуватись принципів конфіденційності щодо особистої інформації студента 3 особливими освітніми потребами та бути терплячим.

Подальші дослідження у цій сфері ми плануємо здійснити у зв'язку із практикою діяльності Служби доступності «Без обмежень» та Ветеранської служби у Львівській політехніці з урахуванням міжнародного досвіду, 3 акцентом на американському та канадському підходах. 